\title{
Article \\ Physicochemical and Antioxidant Capacity of Jujube (Ziziphus jujuba Mill.) at Different Maturation Stages
}

\author{
Juana Reche ${ }^{1}$, Maria Soledad Almansa ${ }^{2}$, Francisca Hernández ${ }^{1}\left(\mathbb{D}\right.$, Asunción Amorós ${ }^{2} \mathbb{C}$ and Pilar Legua ${ }^{1, *(\mathbb{C})}$ \\ 1 Department of Plant Sciences and Microbiology, Universidad Miguel Hernández de Elche. Ctra. de Beniel, \\ Km 3.2, 03312 Orihuela, Alicante, Spain; juana.reche@goumh.umh.es (J.R.); \\ francisca.hernandez@umh.es (F.H.) \\ 2 Department of Applied Biology, Escuela Politécnica Superior de Orihuela, Universidad Miguel Hernández de \\ Elche. Ctra. de Beniel, Km 3.2, 03312 Orihuela, Alicante, Spain; ms.almansa@umh.es (M.S.A.); \\ aamoros@umh.es (A.A.) \\ * Correspondence: p.legua@umh.es; Tel.: +34-966-749-669
}

Citation: Reche, J.; Almansa, M.S.; Hernández, F.; Amorós, A.; Legua, P. Physicochemical and Antioxidant Capacity of Jujube (Ziziphus jujuba Mill.) at Different Maturation Stages. Agronomy 2021, 11, 132.

https: / / doi.org/10.3390/ agronomy11010132

Received: 1 December 2020 Accepted: 8 January 2021 Published: 12 January 2021

Publisher's Note: MDPI stays neutral with regard to jurisdictional clai$\mathrm{ms}$ in published maps and institutional affiliations.

Copyright: (C) 2021 by the authors. Licensee MDPI, Basel, Switzerland. This article is an open access article distributed under the terms and conditions of the Creative Commons Attribution (CC BY) license (https:// creativecommons.org/licenses/by/ $4.0 /)$.
Abstract: Jujube is a crop very resistant to drought and salinity, making it an interesting growing alternative in southeastern Spain. The characteristics of five different cultivars of the jujube fruit have been evaluated and classified into four different maturation stages according to the color of the peel, ranging from green in its most immature stage, to white, yellow, and red in its last, more mature stage. This is due in part to the amount of carotenoids and chlorophylls studied, which vary as the fruit matures. The cultivars 'GAL-E' and 'GAL-T' are the largest in size and weight, followed by 'MSI', 'PSI', and 'DAT', which are the smallest cultivars. The content of phenolic compounds was also analyzed. The antioxidant activity, which was studied by different methods, 2,2'-azino-bis(3ethylbenzothiazoline-6-sulphonic acid (ABTS), 2,2-diphenyl-1-picrylhydrazyl (DPPH), and ferric reducing antioxidant power (FRAP), showed the highest activity in stages 3 and 4 of jujube fruit. The antioxidant activity studied in the hydrophilic and lipophilic fraction by the ABTS method showed the highest peak in stages 1 and 2. This is an important information to know promising cultivars to be used in future breeding programs. Moreover, the maturation stage is relevant to obtain fruit with a high content of bioactive compounds as well as interesting organoleptic properties.

Keywords: carotenoids; flavonols; phenols; total antioxidant activity; Ziziphus jujuba Mill.

\section{Introduction}

Ziziphus jujuba Mill. is a productive tree found in the subtropical regions of Asia and America. It is native to China, where it is widely grown and is well known for its functional properties and its ancestral use in traditional Chinese medicine. There is a book about medicinal herbs in China 'Huangdi Neijing' (475-221 BC) in which jujube is cited as one of the five most valuable fruits [1].

In Spain, it is cultivated in the peninsular southeast, but today, it is considered a marginal crop. Jujube tree is very resistant to salinity and drought, and under water stress, the content of arabinose and glucose in the fruit increases [2]. Its cultivation in arid zones, areas of high altitude, and under complicated edaphic and climatic conditions contributes to the fruit containing a higher content of antioxidants than those cultivated in softer areas [3]. That is why this crop is presented as an interesting alternative in the agriculture of the Spanish East.

The color of the fruit at the beginning is green, and then changes to white, then to yellow, and to red-brown at the end of maturation. These peel colors represent the stage of maturity, with the green stage being the beginning, the white being the ideal stage of maturity for its fresh consumption, the red being the middle stage of maturity and finally the red stage of maturity. 
The fruit of jujube is affected by different factors during the period of fruit development, such as the availability of carbon, water, temperature, and luminous intensity [4]. In the last stage of growth, the fruit ripening period begins, which generally coincides with when the final fruit size is reached. Changes in color occur on the surface of the jujube, as well as changes in aroma, flavor, and texture, which make the fruit accepted for consumption $[5,6]$.

The different uses of jujube for obtaining processed products require different maturity stages, with varying nutritional composition and bioactive properties [1]. For example, for fresh consumption, the most ideal would be the white maturity, while for drying, the most ideal would be the red ripeness, the most mature stage. In addition to changes in color, during this stage, other changes that occur as maturity progresses are the degradation of components responsible for color such as chlorophylls and carotenoids, the decrease in starch content and accumulation of soluble sugars, the decrease in organic acids and phenolic compounds, the emission of volatile compounds characteristic of the fruit, and changes in the texture due to degradation of the components of the cell wall, producing a softening of the fiber [1].

Jujube is a nutritious food and is considered functional because of the high content of vitamins $\mathrm{C}, \mathrm{B} 1$, and B2 as well as flavonoids. In the food industry, it can be used for drying (for infusions or teas) or processing (in recipes for confectionery, jams, and candies [7]), in addition to being used as an additive and flavoring.

The maturity of the fruit is a complex stage of the plant that influences the quality and flavor [8], because of a series of biochemical reactions related to the production of carotenoids, phenolic compounds, hydrolysis of pectins, and changes in the metabolism of sugars and acids $[9,10]$. This implies changes in the physicochemical properties of jujube induced by bioactive compounds, as well as effects of genotypes and drying [11].

The medicinal properties of jujube are numerous; it has an antifertility and antidiabetic effects [12,13]. The fruit contains anti-inflammatory and analgesic properties, and the sedative, hypnotic, and anxiolytic effects of the seed and leaf reduce anxiety and induce sleep through the depression of the nervous system [14]. It also has antifungal, anti-allergic, and high antibacterial activity [15].

Phenolic compounds play a very important role in plants, as they are related to growth, pigmentation, reproduction, and resistance to certain pathogens and diseases [16]. These compounds can vary according to the stage of maturity of the fruit; during the maturation, at stage 3 and stage 4 , the phenolic compounds undergo biosynthesis processes that produce changes in the composition and content of carotenoids, and thus in their derivatives [10]. This causes jujube to have great antioxidant potential with great benefits for human health and for the prevention of diseases such as cancer, cell aging, and cardiovascular diseases [17]. The antioxidant activity of these phytochemicals is due to the fact that they help in the neutralization of free radicals that are harmful to health, thus reducing the oxidative damage of the cells. This cellular protection demonstrates that cardiac, degenerative, and cancer diseases can be avoided [18].

The flavonoid content contributing to the sedative activity [19] varies considerably according to the type of jujube cultivar [20]. Other factors that may influence the antioxidant content are the agronomic conditions, the cultivar, the manipulation in postharvest, and the stage of maturation in which the fruit is found [21-23].

The objective of this work is to perform a physicochemical characterization of jujube properties in four different stages of maturity, and thus to know which state has a higher content of phenols and antioxidants.

\section{Materials and Methods}

\subsection{Plant Material}

Fruits of five cultivars of Ziziphus jujuba Mill., called 'GAL-E' from organic agriculture and 'GAL-T', 'MSI', 'PSI', and 'DAT' from conventional agriculture, were collected in August 2017 and 2018 from a commercial and organic farm located in San Isidro (lati- 
tude $38^{\circ} 10^{\prime} 22.29^{\prime \prime} \mathrm{N}$, longitude $0^{\circ} 51^{\prime} 36.138^{\prime \prime} \mathrm{W}, 19 \mathrm{~m}$ above sea level). Jujube trees were 20 years old; trained planted in a vase; spaced at $4 \mathrm{~m} \times 4 \mathrm{~m}$; and grown with the similar conditions of irrigation, fertilization, and pest control, except the cultivar cultivated in organic conditions had fertilization that was organic and without pest control. Samples in this experiment were harvested from August to October in both years. For each cultivar, 600 fruits from 5 trees (120 fruits per tree) were hand-harvested and immediately transported under ventilated conditions to the laboratory. These fruits were classified into four different maturation stages each with 30 fruits (see Figure 1):

Stage 1: The most immature stage, with a green color over its entire surface.

Stage 2: The stage of perfect maturation, with a white-cream color.

Stage 3: Red spots begin to appear on more than $20 \%$ of their surface.

Stage 4: Red spots on more than $60 \%$ of the surface of the fruit.

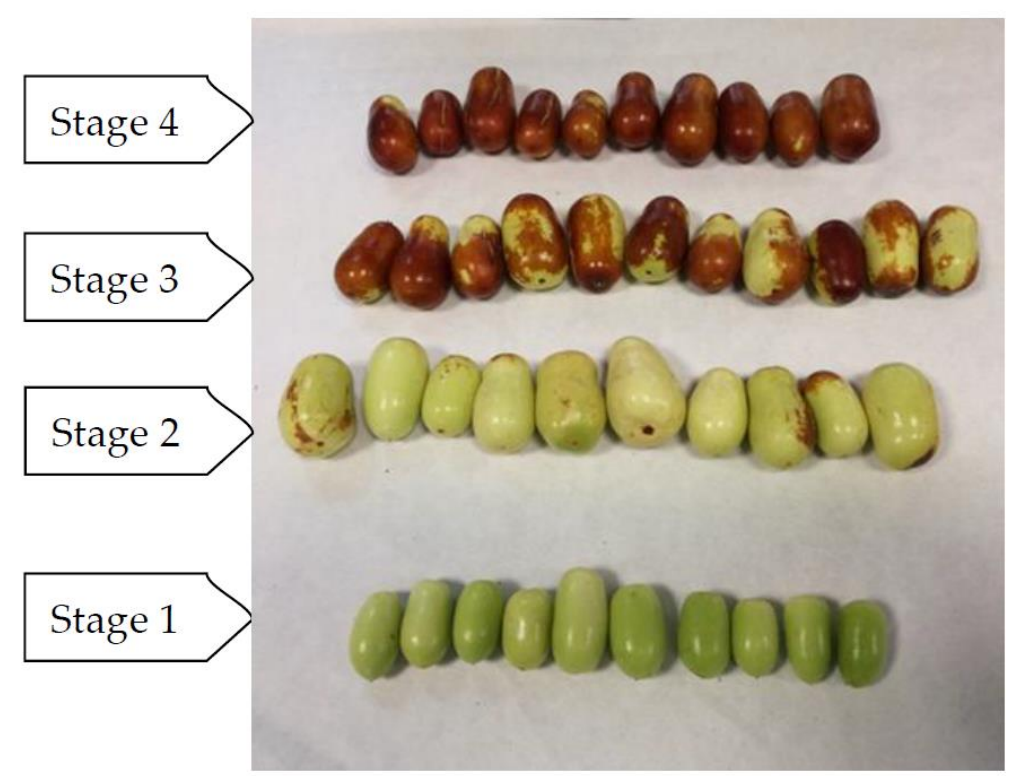

Figure 1. Different stages of maturation of jujube fruits.

\subsection{Physicochemical Characteristics Analysis}

Once in the laboratory, the jujube fruits were immediately classified and processed. The following parameters were measured in each fruit (30 fruits/cultivar and stage):

- Equatorial diameter and fruit height $(\mathrm{mm})$ using a digital caliper (model CD-15 DC; Mitutoyo (UK) Ltd., Telford, UK), with $0.01 \mathrm{mM}$ accuracy;

- Fruit weight (g) was measured using a digital balance (model BL-600; Sartorius, Madrid, Spain), with an accuracy of $0.01 \mathrm{~g}$;

- Color measurement was done on the peel of the fruit on two opposite faces at the equatorial zone. Color was assessed according to the Commission Internationale de $\mathrm{l}^{\prime}$ Eclairage (CIELab) and expressed as $\mathrm{L}^{*}, \mathrm{a}^{*}$, and $\mathrm{b}^{*}$, with a colorimeter Minolta C-300 Chroma Meter (Minolta Corp., Osaka, Japan) coupled to a Minolta DP-301 data processor.

The fruits were grouped in four different stages and, from each stage, three replicates were made to determine the moisture content according to the methodology proposed by Reche et al. (2019) and to quantify all parameters.

\subsection{Chlorophyll, Carotenoid, Phenolic Content, and Antioxidant Activities}

The chlorophylls were extracted from each sample using $80 \%$ acetone in a 1:2 ratio $(w: v)$. The sample was crushed with sea sand in a mortar, and then centrifuged at 12,000 $\mathrm{g}$ for $20 \mathrm{~min}$ at $4^{\circ} \mathrm{C}$. The absorbance was measured with a Helios Gamma spectrophotometer (model, UVG 1002E, Helios, Cambridge, UK) at 664 and $647 \mathrm{~nm}$, and the results were expressed in $\mathrm{mg}$ of $100 \mathrm{~g}^{-1}$ fresh weight (fw) according to [24]. Total carotenoids were 
extracted from each sample using $5 \mathrm{~g}$ of sample with $6 \mathrm{~mL}$ of ethyl acetate and $6 \mathrm{~mL}$ of $50 \mathrm{mM}$ Tris-acetate buffer, $\mathrm{pH}$ 6.0, and then centrifuged at $2000 \mathrm{~g}$ for $20 \mathrm{~min}$ at $4{ }^{\circ} \mathrm{C}$. The aqueous (hydrophilic phase) and organic (lipophilic phase) phases were separated. Absorbance of the supernatant (lipophilic phase) was read at $450 \mathrm{~nm}$ and the result was expressed in mg of $\beta$-carotene equivalent per $100 \mathrm{~g}^{-1}$ fresh weight, and $\varepsilon^{1 \%} \mathrm{~cm}=2560$ was taken into account.

The protein content was analyzed by the method of [25] using the Bio-Rad reactive. A standard curve of pure bovine serum albumin (BSA) was used for quantification. The results were expressed as $\mathrm{mg} 100 \mathrm{~g}^{-1} \mathrm{fw}$.

The total antioxidant activity (TAA), phenols, flavonols, and flavonoids in the jujube fruit were determined according to [26].

The antioxidant activity of the fruit in the hydrophilic (H-TAA) and lipophilic (L-TAA) phase, described above, was also measured, following the method described by [26]. The reaction mixture contained $10 \mathrm{mM}$ 2,2'-azino-bis(3-ethylbenzothiazoline-6-sulphonic acid (ABTS), $1 \mathrm{mM}$ hydrogen peroxide, and $10 \mathrm{mM}$ peroxidase in a total volume of $1 \mathrm{~mL}$ of $50 \mathrm{mM}$ glycine- $\mathrm{HCl}$ buffer ( $\mathrm{pH} 4.5$ ) for H-TAA, or ethyl acetate for L-TAA. The reaction was monitored at $730 \mathrm{~nm}$ until a stable absorbance was obtained using a UNICAM Helios spectrophotometer (Thermo Spectronic, Cambridge, UK). After that, a suitable amount of jujube fruit extract was added and the observed decrease in absorbance was determined. A calibration curve was performed with Trolox as standard antioxidant for both H-TAA and L-TAA. The results were expressed in milligrams of Trolox equivalent of $100 \mathrm{~g}^{-1}$ fresh weight ( $\mathrm{fw}$ ).

The TAA was determined by three different methods, $\mathrm{ABTS}^{+}$according to [27]; DPPH radical method (2,2-diphenyl-1-picrylhydrazyl), according to [28]; and ferric reducing antioxidant power (FRAP), as described by [29], as well as with a methanol extract prepared according to [30]. Calibration curves, in the range 0.5-5.0 mMol Trolox $\mathrm{L}^{-1}$, were prepared for all three methods and showed good linearity $\left(R^{2}=0.998\right)$. All antioxidant capacity analyses were run in triplicate. The determinations were made with a visible UV spectrophotometer (Helios Gamma model, UVG 1002E, Helios, Cambridge, UK) and the results were expressed in fresh weight $\mathrm{mM}$ Trolox (fw).

The total phenolic compounds, polyphenols (TP), were quantified in the hydrophilic phase by the method of [31], and using the Folin-Ciocalteu reagent. Briefly, $25 \mu \mathrm{L}$ of hydrophilic extracts was mixed with $2.5 \mathrm{~mL}$ of Folin-Ciocalteau. The mixture was incubated for $2 \mathrm{~min}$ at room temperature and $2 \mathrm{~mL}$ of sodium carbonate $\left(75 \mathrm{~g} \mathrm{~L}^{-1}\right)$ was added and vortexed. Finally, the mixture was incubated at $50{ }^{\circ} \mathrm{C}$ for $5 \mathrm{~min}$ and the absorbance was measured at $760 \mathrm{~nm}$. A calibration curve was performed with gallic acid, and the results were expressed in mg of gallic acid $100 \mathrm{~g}^{-1} \mathrm{fw}$.

Total flavonols and total flavonoids were extracted using $80 \%$ methanol and quantified by spectrophotometry according to [32,33]. The analysis of total flavonoids (mg rutin equivalents $100 \mathrm{~g}^{-1} \mathrm{fw}$ ) was performed after using $5 \% \mathrm{NaNO}_{2}, 10 \% \mathrm{AlCl}_{3}$, and $1 \mathrm{M} \mathrm{NaOH}$; absorbance was measured at $512 \mathrm{~nm}$ on a Helios Gamma spectrophotometer The results obtained were expressed in $\mu \mathrm{g}$ rutin equivalents $100 \mathrm{~g}^{-1} \mathrm{fw}$.

Quantification of total flavonols was performed by spectrophotometry following the method of [33], using $\mathrm{AlCl}_{3}\left(2 \mathrm{mg} \mathrm{mL}^{-1}\right)$ and sodium acetate $\left(50 \mathrm{mg} \mathrm{mL}^{-1}\right)$, and absorbance was measured at $440 \mathrm{~nm}$ on a Helios Gamma spectrophotometer (model, UVG 1002E; Helios, Cambridge, UK). The results of total flavonols were expressed in $\mu \mathrm{g}$ rutin equivalents $100 \mathrm{~g}^{-1} \mathrm{fw}$. For this, a rutin calibration line was performed whose equation was $y=4.479 x+0.06773$, with a correlation of $99.88 \%$.

\subsection{Statistical Analysis}

Statistical analyses were performed using the software package SPSS 18.0 for Windows (SPSS Science, Chicago, IL, USA). A basic descriptive statistical analysis was followed by a one-way analysis of variance (ANOVA) test for mean comparisons. The method used 
to discriminate among the means (multiple range test) was Fisher's LSD (least significant difference) procedure at a $95.0 \%$ confidence level.

\section{Results}

\subsection{Biochemical Properties of Jujube Fruit}

During maturation, there is a considerable weight gain (Figure 2). In the cultivars 'GAL-E', 'GAL-T', and 'MSI', the maximum weight was reached in stage 3 of maturation. In contrast, the cultivar 'PSI' had the highest weight in stage 2, with $7.16 \mathrm{~g}$. The cultivar 'DAT' increased its weight progressively throughout the whole maturation, reaching the maximum weight of the fruit at the stage 4 , with $14.93 \mathrm{~g}$.
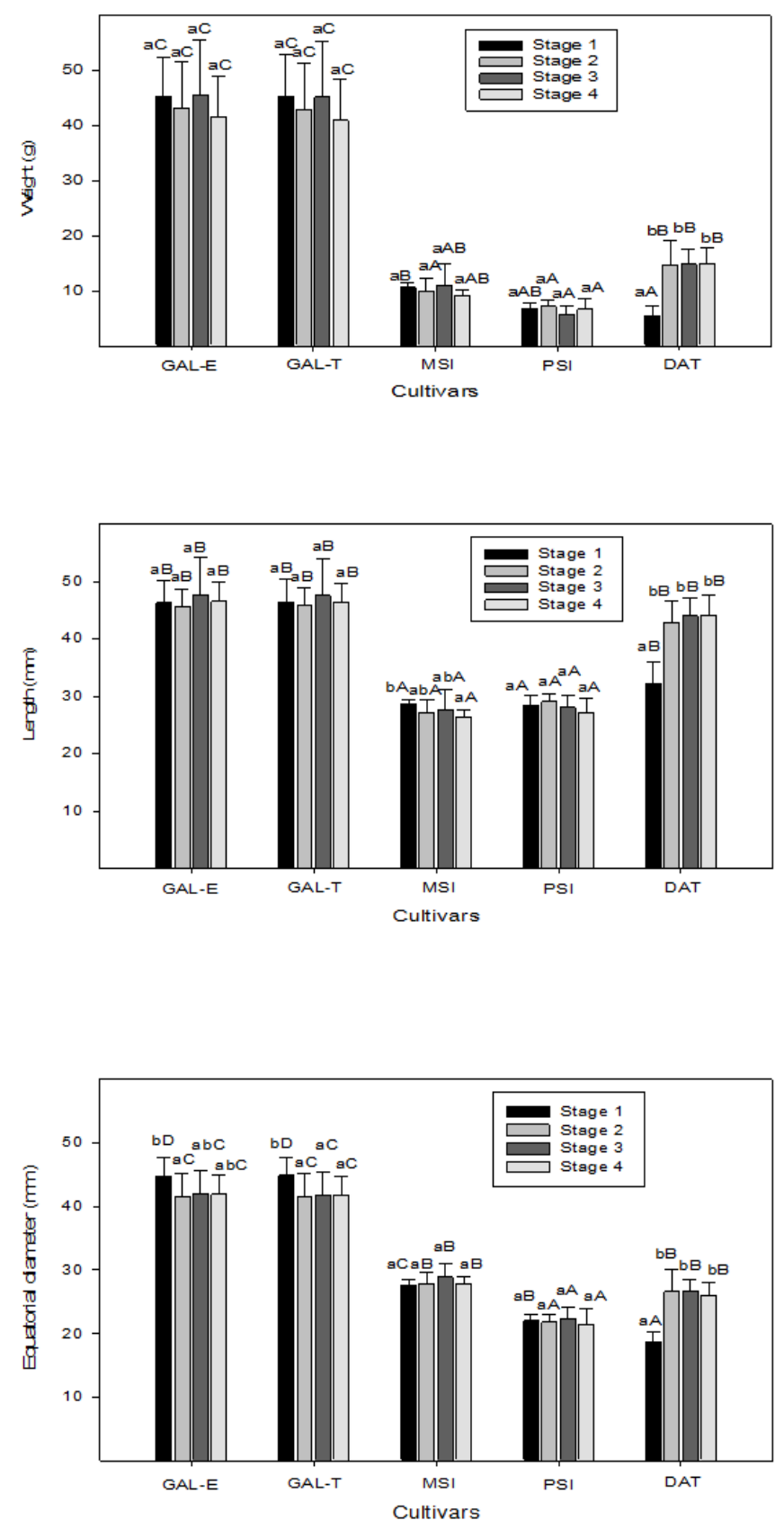

Figure 2. Weight, length, and equatorial diameter of jujube fruits as affected by cultivar and stage of development. The same letters $(a, b, c)$ indicate non significance $(p<0.05)$ at the different stages. The same letters $(A, B, C \ldots)$ indicate significance $(p<0.05)$ in the different cultivars. 
The cultivars of greater weight and size were 'GAL-E' and 'GAL-T', with values of $45.16 \mathrm{~g}$ and $45.08 \mathrm{~g}$, respectively. On the other hand, the cultivars 'DAT', 'MSI', and 'PSI' showed the lowest weight and size of fruit. The cultivar 'DAT' differs from the rest by its elongated shape, instead of the round shape of the others.

The color measurements of $\mathrm{L}^{*}, \mathrm{a}^{*}, \mathrm{~b}^{*}$, Chroma, and Hue are presented in Table 1 . In all stages of maturation, the color changed, from greener tones in stage 1, white in stage 2, yellows and reds in stage 3 , and a higher value of red tones for stage 4 . This was common in the five cultivars.

There is a decrease in the luminosity according to the last stage of ripeness of the fruit. This is due to the increase of the red tones. This fact was more pronounced in the cultivar 'MSI'. The parameter a* obtained values from negative to positive as the maturity advanced in the cultivars 'MSI', 'PSI', and 'DAT'; however, in the cultivars 'GAL', this value increased. On the other hand, the $b^{*}$ parameter in these cultivars decreased slightly during maturity, but in the latter stage, it underwent a small increase, contrary to the cultivars 'MSI' , $P S I^{\prime}$, and 'DAT', which decreased considerably throughout the maturity stage.

\subsection{Total Proteins, Carotenoids, and Chlorophylls in Jujube Fruit}

The proteins showed a high content in stage 1, being higher for the 'MSI' variety of $0.65 \mathrm{mg}$ protein $\mathrm{g}^{-1} \mathrm{fw}$, followed by 'DAT', 'GAL-E', and 'PSI'; on the other hand, 'GAL-T', with $0.43 \mathrm{mg}$ protein $\mathrm{g}^{-1} \mathrm{fw}$, obtained the lowest value. This protein value can even be decreased by half in its last stage of maturation owing to the enzymatic synthesis that occurs in the fruit (Table 2).

The cultivar 'PSI' showed the highest carotenoid content, with a value of $0.46 \mathrm{mg}$ $\beta$-caronet eq $100 \mathrm{~g}^{-1} \mathrm{fw}$ in stage 2 ; followed by the cultivar ' $\mathrm{MSI}^{\prime}$, with $0.39 \mathrm{mg} \beta$-caronet eq $100 \mathrm{~g}^{-1} \mathrm{fw}$ in the most mature stage of the fruit; and 'DAT', with a content of $0.32 \mathrm{mg}$ $\beta$-caronet eq $100 \mathrm{~g}^{-1} \mathrm{fw}$ in stage 1 . The GAL cultivars were the least carotenoid in their four stages.

Chlorophylls a showed the highest level in the most mature stage, stage 4, with the cultivar 'DAT' with a value of $0.52 \mathrm{mg} 100 \mathrm{~g}^{-1} \mathrm{fw}$ and the cultivar 'MSI' with $0.36 \mathrm{mg} 100 \mathrm{~g}^{-1} \mathrm{fw}$.

Chlorophylls b showed a clear tendency, in all cultivars, in which the highest content was in stage 1, progressively decreasing as maturation progressed. The cultivar 'GAL-T' was the one that showed a high level with $0.59 \mathrm{mg} 100 \mathrm{~g}^{-1} \mathrm{fw}$, followed by 'GAL-E' and

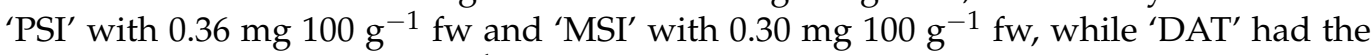

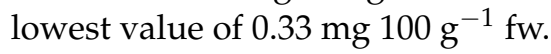

The total content of chlorophylls was higher in the cultivars 'GAL-T', 'GAL-E', and 'PSI' in their more immature stages, stage 1 and 2.

The 'GAL-T' cultivar was the one that showed a high level with $0.72 \mathrm{mg} 100 \mathrm{~g}^{-1} \mathrm{fw}$, followed, at almost half of the value, by 'GAL-E', with $0.46 \mathrm{mg} 100 \mathrm{~g}^{-1} \mathrm{fw}$ and the cultivars 'PSI' with $0.36 \mathrm{mg} 100 \mathrm{~g}^{-1} \mathrm{fw}$ and 'MSI' with $0.33 \mathrm{mg} 100 \mathrm{~g}^{-1} \mathrm{fw}$. The cultivar obtained the lowest value in stage 4 , with $0.29 \mathrm{mg} 100 \mathrm{~g}^{-1} \mathrm{fw}$. 
Table 1. Color parameters of five Spanish cultivars as affected by cultivar and stage of development.

\begin{tabular}{|c|c|c|c|c|c|c|c|c|c|c|c|c|c|c|c|c|}
\hline \multirow[b]{2}{*}{$L^{*}$} & \multicolumn{4}{|c|}{ 'GAL-E' } & \multicolumn{2}{|c|}{ ‘GAL-T’ } & \multicolumn{4}{|c|}{${ }^{\prime} \mathrm{MSI}^{\prime}$} & \multicolumn{2}{|l|}{ 'PSI' } & \multicolumn{3}{|c|}{${ }^{\prime} \mathrm{DAT}^{\prime}$} & \multirow[b]{2}{*}{ cA } \\
\hline & Stage 1 & 72.85 & \pm 2.78 & $\mathrm{bA}$ & 72.64 & \pm 2.78 & bA & 73.24 & \pm 2.67 & $\mathrm{cA}$ & 72.15 & \pm 2.65 & bA & 71.01 & \pm 3.33 & \\
\hline & Stage 2 & 75.10 & \pm 2.20 & $\mathrm{bAB}$ & 74.89 & \pm 2.21 & $\mathrm{bAB}$ & 72.50 & \pm 5.31 & $\mathrm{cA}$ & 72.75 & \pm 3.17 & $\mathrm{bA}$ & 75.77 & \pm 2.04 & $\mathrm{cB}$ \\
\hline & Stage 3 & 70.24 & \pm 2.21 & $\mathrm{aC}$ & 70.04 & \pm 2.21 & $\mathrm{aC}$ & 50.81 & \pm 5.47 & $\mathrm{bA}$ & 69.26 & \pm 2.91 & $\mathrm{bC}$ & 55.98 & \pm 8.15 & $\mathrm{bB}$ \\
\hline \multirow[t]{4}{*}{$a^{*}$} & Stage 1 & -14.00 & \pm 1.73 & $\mathrm{bB}$ & -13.70 & \pm 1.74 & $\mathrm{bB}$ & -15.90 & \pm 1.77 & $\mathrm{aAB}$ & -16.60 & \pm 1.24 & $\mathrm{aA}$ & -15.00 & \pm 5.04 & $\mathrm{aAB}$ \\
\hline & Stage 2 & -5.96 & \pm 1.85 & $\mathrm{cC}$ & -5.73 & \pm 1.83 & $\mathrm{cC}$ & -8.95 & \pm 5.12 & $\mathrm{bB}$ & -12.00 & \pm 2.99 & $\mathrm{bA}$ & -10.60 & \pm 1.49 & $\mathrm{aAB}$ \\
\hline & Stage 3 & -3.27 & \pm 2.79 & $\mathrm{dA}$ & -3.17 & \pm 2.79 & $\mathrm{dA}$ & 11.85 & \pm 6.51 & $\mathrm{cC}$ & -5.13 & \pm 3.62 & $\mathrm{cA}$ & 5.67 & \pm 8.07 & $\mathrm{bB}$ \\
\hline & Stage 4 & -16.20 & \pm 1.83 & $\mathrm{aA}$ & -16.10 & \pm 1.83 & $\mathrm{aA}$ & 20.33 & \pm 1.58 & $\mathrm{dD}$ & -0.48 & \pm 3.71 & $\mathrm{~dB}$ & 16.89 & \pm 2.93 & $\mathrm{cC}$ \\
\hline \multirow[t]{4}{*}{$b^{*}$} & Stage 1 & 38.03 & \pm 0.91 & $\mathrm{aA}$ & 37.72 & \pm 0.91 & $\mathrm{aA}$ & 39.39 & \pm 1.57 & $\mathrm{cB}$ & 39.75 & \pm 0.81 & $c B$ & 38.61 & \pm 1.91 & $\mathrm{dAB}$ \\
\hline & Stage 2 & 36.89 & \pm 1.22 & $\mathrm{aA}$ & 36.58 & \pm 1.22 & $\mathrm{aA}$ & 36.98 & \pm 0.99 & $\mathrm{cA}$ & 38.46 & \pm 1.16 & $\mathrm{bcB}$ & 36.17 & \pm 1.41 & cA \\
\hline & Stage 3 & 36.99 & \pm 1.32 & $\mathrm{aC}$ & 36.81 & \pm 1.33 & $\mathrm{aC}$ & 29.75 & \pm 4.14 & $\mathrm{bA}$ & 36.39 & \pm 1.18 & $\mathrm{bC}$ & 33.48 & \pm 2.12 & $\mathrm{bB}$ \\
\hline & Stage 4 & 40.01 & \pm 1.86 & $\mathrm{bD}$ & 39.99 & \pm 1.86 & $\mathrm{bD}$ & 19.33 & \pm 3.89 & $\mathrm{aA}$ & 33.79 & \pm 4.78 & $\mathrm{aC}$ & 28.88 & \pm 3.95 & $\mathrm{aB}$ \\
\hline \multirow[t]{4}{*}{$C^{*}$} & Stage 1 & 40.54 & \pm 1.29 & $\mathrm{bA}$ & 40.17 & \pm 1.29 & $\mathrm{bA}$ & 45.51 & \pm 1.94 & $\mathrm{~dB}$ & 43.09 & \pm 0.95 & $\mathrm{~dB}$ & 41.67 & \pm 2.58 & $\mathrm{aAB}$ \\
\hline & Stage 2 & 37.41 & \pm 1.28 & $\mathrm{aA}$ & 37.06 & \pm 1.27 & $\mathrm{aA}$ & 38.35 & \pm 1.35 & $\mathrm{cA}$ & 40.39 & \pm 1.54 & cB & 37.72 & \pm 1.65 & $\mathrm{aA}$ \\
\hline & Stage 3 & 37.23 & \pm 1.23 & $\mathrm{aC}$ & 37.04 & \pm 1.19 & $\mathrm{aC}$ & 32.70 & \pm 3.19 & $\mathrm{bA}$ & 36.91 & \pm 1.37 & $\mathrm{bC}$ & 34.82 & \pm 1.89 & $\mathrm{bB}$ \\
\hline & Stage 4 & 43.22 & \pm 2.19 & $\mathrm{cC}$ & 43.14 & \pm 2.19 & $\mathrm{cC}$ & 28.22 & \pm 2.61 & $\mathrm{aA}$ & 34.01 & \pm 4.58 & $\mathrm{aB}$ & 33.65 & \pm 3.19 & $\mathrm{cB}$ \\
\hline \multirow{2}{*}{$\mathrm{H}$} & Stage 3 & -1.16 & \pm 0.94 & $\mathrm{aA}$ & -1.16 & \pm 0.94 & $\mathrm{aA}$ & 1.18 & \pm 0.21 & $\mathrm{cB}$ & -1.11 & \pm 0.92 & $\mathrm{aA}$ & 0.46 & \pm 1.36 & $\mathrm{bB}$ \\
\hline & Stage 4 & -1.18 & \pm 0.03 & $\mathrm{aA}$ & -1.18 & \pm 0.03 & $\mathrm{aA}$ & 0.75 & \pm 0.11 & $\mathrm{bC}$ & 0.002 & \pm 1.56 & $\mathrm{bB}$ & 1.03 & \pm 0.11 & $\mathrm{bC}$ \\
\hline
\end{tabular}

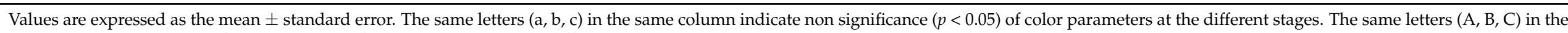
same row indicate non significance $(p<0.05)$ of color parameters in the different cultivars. $\mathrm{L}^{*}$ : lightness, $\mathrm{a}^{*}$ : red-greenness coordinates, $\mathrm{b}^{*}$ : blue-yellowness coordinates, $\mathrm{C}^{*}$ : chromaticity, H: hue angle. 
Table 2. Photosynthetic pigments (mg $100 \mathrm{~g}^{-1} \mathrm{fw}$ ) of jujube fruits as affected by cultivar and stage of development.

\begin{tabular}{|c|c|c|c|c|c|c|c|c|c|c|c|c|c|c|c|c|}
\hline & & & GAL-E' & & & 'GAL-T’ & & & 'MSI' & & & & & & ‘DAT' & \\
\hline \multirow{3}{*}{$\begin{array}{c}\text { PROTEINS } \\
\mathrm{mg} \text { protein } \mathrm{g}^{-1} \mathrm{fw}\end{array}$} & Stage 1 & 0.60 & \pm 0.04 & $\mathrm{bB}$ & 0.43 & \pm 0.07 & $\mathrm{aA}$ & 0.65 & \pm 0.04 & $\mathrm{bB}$ & 0.62 & \pm 0.02 & $\mathrm{aB}$ & 0.64 & \pm 0.06 & $\mathrm{bB}$ \\
\hline & Stage 2 & 0.48 & \pm 0.05 & $\mathrm{abA}$ & 0.44 & \pm 0.04 & $\mathrm{aA}$ & 0.68 & \pm 0.04 & $\mathrm{bBC}$ & 0.76 & \pm 0.01 & $\mathrm{bC}$ & 0.64 & \pm 0.01 & $\mathrm{bB}$ \\
\hline & Stage 3 & 0.52 & \pm 0.03 & $\mathrm{bBC}$ & 0.51 & \pm 0.03 & $\mathrm{aB}$ & 0.49 & \pm 0.01 & $\mathrm{aB}$ & 0.60 & \pm 0.03 & $\mathrm{aC}$ & 0.36 & \pm 0.01 & $\mathrm{aA}$ \\
\hline \multirow{4}{*}{$\begin{array}{l}\text { CAROTENOIDS } \\
\text { mg } \beta \text {-caroten eq. } \\
100 \mathrm{~g}^{-1} \mathrm{fw}\end{array}$} & Stage 1 & 0.25 & \pm 0.01 & $\mathrm{aA}$ & 0.22 & \pm 0.02 & $\mathrm{aA}$ & 0.39 & \pm 0.01 & $\mathrm{aC}$ & 0.37 & \pm 0.03 & $\mathrm{cC}$ & 0.32 & \pm 0.01 & $\mathrm{bB}$ \\
\hline & Stage 2 & 0.24 & \pm 0.01 & $\mathrm{aB}$ & 0.18 & \pm 0.02 & $\mathrm{aA}$ & 0.35 & \pm 0.03 & $\mathrm{aC}$ & 0.46 & \pm 0.01 & $\mathrm{dD}$ & 0.29 & \pm 0.01 & $\mathrm{bB}$ \\
\hline & Stage 3 & 0.16 & \pm 0.02 & $\mathrm{bA}$ & 0.23 & \pm 0.02 & $\mathrm{aB}$ & 0.31 & \pm 0.03 & $\mathrm{aC}$ & 0.29 & \pm 0.01 & $\mathrm{bC}$ & 0.22 & \pm 0.01 & $\mathrm{aAB}$ \\
\hline & Stage 4 & 0.22 & \pm 0.01 & $\mathrm{bAB}$ & 0.18 & \pm 0.01 & $\mathrm{aA}$ & 0.39 & \pm 0.02 & $\mathrm{aC}$ & 0.19 & \pm 0.01 & $\mathrm{aAB}$ & 0.25 & \pm 0.01 & $\mathrm{aB}$ \\
\hline \multirow{4}{*}{$\begin{array}{l}\text { CHLOROPHYLLS a } \\
\text { mg } 100 \mathrm{~g}^{-1} \mathrm{fw}\end{array}$} & Stage 1 & 0.09 & \pm 0.01 & $\mathrm{aC}$ & 0.13 & \pm 0.02 & $\mathrm{aD}$ & 0.03 & \pm 0.01 & $\mathrm{aAB}$ & 0.01 & \pm 0.01 & $\mathrm{aA}$ & 0.05 & \pm 0.01 & $\mathrm{aB}$ \\
\hline & Stage 2 & 0.44 & \pm 0.37 & $\mathrm{aA}$ & 0.08 & \pm 0.01 & $\mathrm{aA}$ & 0.07 & \pm 0.01 & $\mathrm{aA}$ & 0.10 & \pm 0.00 & $\mathrm{aA}$ & 0.03 & \pm 0.01 & $\mathrm{aA}$ \\
\hline & Stage 3 & 0.12 & \pm 0.03 & $\mathrm{aA}$ & 0.09 & \pm 0.05 & $\mathrm{aA}$ & 0.06 & \pm 0.01 & $\mathrm{aA}$ & 0.09 & \pm 0.02 & $\mathrm{aA}$ & 0.05 & \pm 0.00 & $\mathrm{aA}$ \\
\hline & Stage 4 & 0.33 & \pm 0.25 & $\mathrm{aA}$ & 0.12 & \pm 0.01 & $\mathrm{aA}$ & 0.36 & \pm 0.29 & $\mathrm{aA}$ & 0.07 & \pm 0.02 & $\mathrm{aA}$ & 0.52 & \pm 0.12 & $\mathrm{aA}$ \\
\hline \multirow{4}{*}{$\begin{array}{l}\text { CHLOROPHYLLS b } \\
\text { mg } 100 \mathrm{~g}^{-1} \mathrm{fw}\end{array}$} & Stage 1 & 0.36 & \pm 0.01 & $\mathrm{aB}$ & 0.59 & \pm 0.07 & $\mathrm{bC}$ & 0.30 & \pm 0.01 & $\mathrm{aAB}$ & 0.36 & \pm 0.01 & $\mathrm{cB}$ & 0.21 & \pm 0.01 & $\mathrm{bA}$ \\
\hline & Stage 2 & 0.20 & \pm 0.12 & $\mathrm{aAB}$ & 0.37 & \pm 0.03 & $\mathrm{aB}$ & 0.20 & \pm 0.01 & $\mathrm{aAB}$ & 0.27 & \pm 0.00 & $\mathrm{bAB}$ & 0.18 & \pm 0.01 & $\mathrm{bA}$ \\
\hline & Stage 3 & 0.36 & \pm 0.08 & $\mathrm{aB}$ & 0.35 & \pm 0.02 & $\mathrm{aB}$ & 0.18 & \pm 0.02 & $\mathrm{aA}$ & 0.28 & \pm 0.02 & $\mathrm{bAB}$ & 0.16 & \pm 0.00 & $\mathrm{bA}$ \\
\hline & Stage 4 & 0.19 & \pm 0.13 & $\mathrm{aAB}$ & 0.31 & \pm 0.06 & $\mathrm{aB}$ & 0.15 & \pm 0.10 & $\mathrm{aAB}$ & 0.21 & \pm 0.01 & $\mathrm{aAB}$ & 0.01 & \pm 0.04 & $\mathrm{aA}$ \\
\hline \multirow{2}{*}{$\begin{array}{l}\text { TOTAL CHLOROP. } \\
\text { mg } 100 \mathrm{~g}^{-1} \mathrm{fw}\end{array}$} & Stage 3 & 0.48 & \pm 0.10 & $\mathrm{aB}$ & 0.44 & \pm 0.06 & $\mathrm{aB}$ & 0.24 & \pm 0.03 & $\mathrm{aA}$ & 0.37 & \pm 0.04 & $\mathrm{aAB}$ & 0.21 & \pm 0.01 & $\mathrm{aA}$ \\
\hline & Stage 4 & 0.51 & \pm 0.11 & $\mathrm{aA}$ & 0.43 & \pm 0.07 & $\mathrm{aA}$ & 0.48 & \pm 0.16 & $\mathrm{aA}$ & 0.29 & \pm 0.02 & $\mathrm{aA}$ & 0.48 & \pm 0.09 & $\mathrm{aA}$ \\
\hline
\end{tabular}

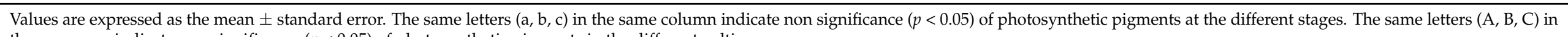
the same row indicate non significance $(p<0.05)$ of photosynthetic pigments in the different cultivars. 


\subsection{Total Phenols, Flavonoids, and Flavonols of Jujube Fruit}

The cultivars 'GAL-E', 'MSI', 'PSI', and 'DAT' showed very high values of phenols in stages 1 and 2 (Figure 3). In contrast, 'GAL-T' showed the highest value in stage 4, with $456.31 \mathrm{mg}$ GAE $100 \mathrm{~g}^{-1} \mathrm{fw}$. The cultivar 'GAL-E' was the one with the highest content of phenols, with $574.08 \mathrm{mg}$ GAE $100 \mathrm{~g}^{-1} \mathrm{fw}$, followed by 'MSI' with $553.42 \mathrm{mg}$ GAE $100 \mathrm{~g}^{-1}$ $\mathrm{fw}$ and 'PSI' with $517.14 \mathrm{mg}$ GAE $100 \mathrm{~g}^{-1} \mathrm{fw}$. The lowest values were obtained in the 'DAT'

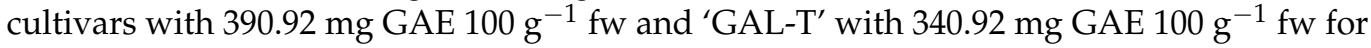
the same stage.
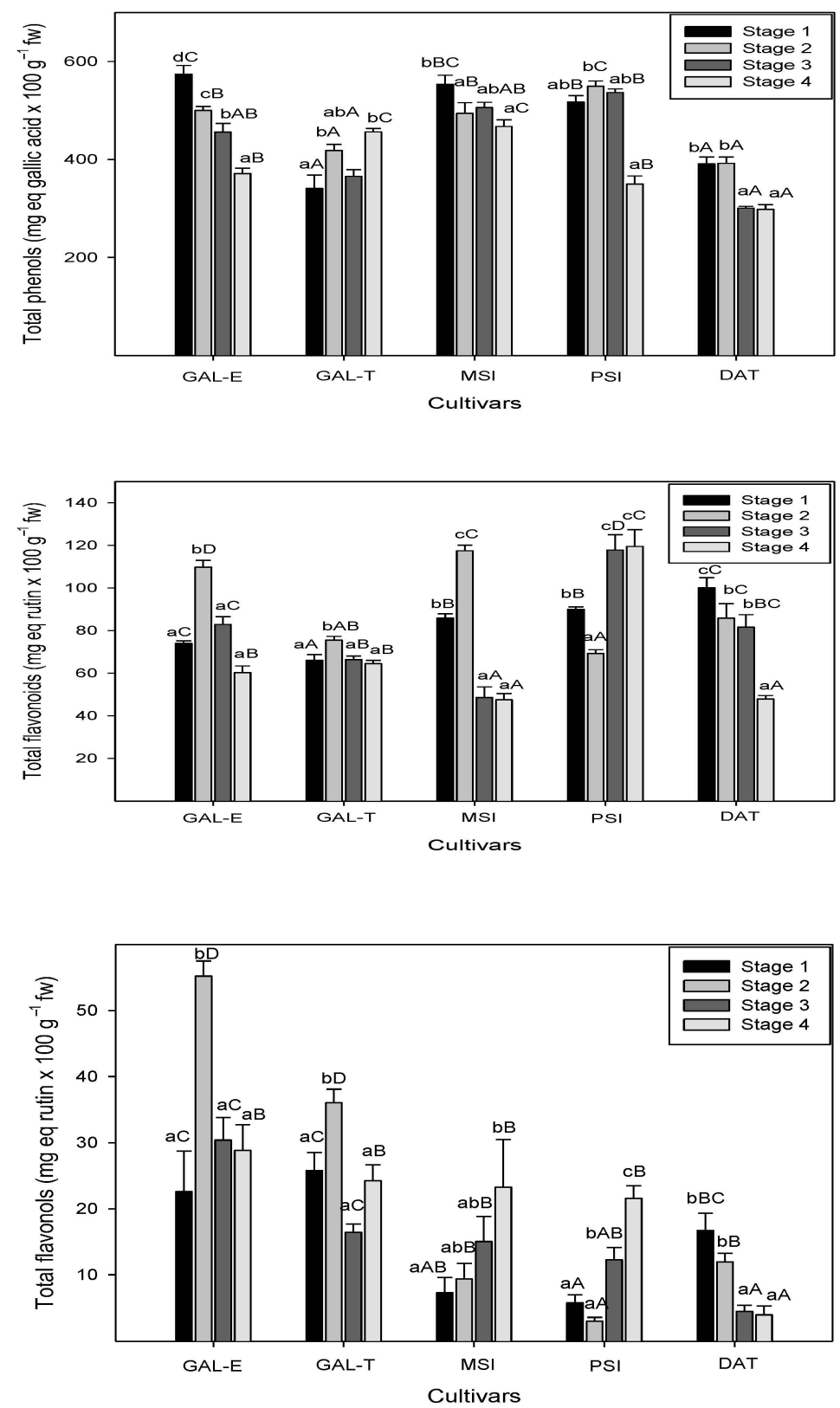

Figure 3. Total phenols, flavonoids, and flavonols contents of jujube fruits as affected by cultivar and stage of development. The same letters $(\mathrm{a}, \mathrm{b}, \mathrm{c})$ indicate non significance $(p<0.05)$ at the different stages. The same letters $(A, B, C \ldots)$ indicate significance $(p<0.05)$ in the different cultivars.

The flavonoids reached the highest peak in the cultivar 'PSI' in its last stage of maturation, with a content of $119.53 \mu \mathrm{g}$ eq. rutin $100 \mathrm{~g}^{-1} \mathrm{fw}$, and in stage 3 , with the value of $117.81 \mu \mathrm{g}$ eq. rutin $100 \mathrm{~g}^{-1} \mathrm{fw}$. These high values are followed by stage 2 of the cultivar 'MSI', with $117.48 \mu \mathrm{g}$ eq. rutin $100 \mathrm{~g}^{-1} \mathrm{fw}$. 
In cultivars 'GAL-E', 'GAL-T', and 'MSI', stage 2 was where the highest content of flavonoids was reached, which then drcreased considerably as the fruit matured. The cultivar 'DAT' in stage 1 already obtained its highest value, of $100.14 \mu \mathrm{g}$ eq. rutin $100 \mathrm{~g}^{-1} \mathrm{fw}$, which gradually decreased until stage 4, with the lowest value of $47.92 \mu \mathrm{g}$ eq. rutin $100 \mathrm{~g}^{-1} \mathrm{fw}$.

Something similar happens with flavanols. They reach their highest value in stage 2 of cultivars 'GAL-E' and 'GAL-T', with 55.19 and $36.02 \mu \mathrm{g}$ eq. rutin $100 \mathrm{~g}^{-1} \mathrm{fw}$, respectively. In contrast, the cultivar 'DAT' had the highest value in stage 1, with $16.71 \mu \mathrm{g}$ eq. rutin $100 \mathrm{~g}^{-1} \mathrm{fw}$. Cultivars 'MSI' and 'PSI' in stage 4 showed the highest content in flavonols, with 23.26 and $21.58 \mu \mathrm{g}$ eq. rutin $100 \mathrm{~g}^{-1} \mathrm{fw}$, respectively. In all cultivars except the latter two, the flavonols obtained the highest value in their most immature stages and decreased, as did the flavonoids, as the stage of maturity of the jujube fruit increased.

\subsection{Total Antioxidant Activity (TAA) of Jujube Fruit}

The total antioxidant activity (TAA) was studied in the jujube fruit in four different stages of maturity and by different methods (Table 3). TAA was quantified with the ABTS, DPPH, and FRAP methods, besides studying the antioxidant activity in the hydrophilic and lipophilic fractions by the ABTS method.

In general, the antioxidant activity in H-TAA and L-TAA was higher in the more immature stages of the fruit, whereas the antioxidant activity by ABTS, DPPH, and FRAP was higher in their more mature stages, that is, stage 3 and, above all, in stage 4 .

The antioxidant activity in H-TAA took place in stage 2 , where it reached the highest value, which then decreased in stage 3 and, in some cases, it rose again in stage 4 in a small proportion. The highest peak of activity was obtained in the cultivar 'MSI', with a value of $941.24 \mathrm{mM}$ Trolox $100 \mathrm{~g}^{-1} \mathrm{fw}$, followed by the cultivars 'PSI' and 'DAT', with values of $864.02 \mathrm{mM}$ Trolox $100 \mathrm{~g}^{-1} \mathrm{fw}$ and $794.63 \mathrm{mM}$ Trolox $100 \mathrm{~g}^{-1} \mathrm{fw}$, respectively. In contrast, the cultivar 'GAL-E' showed its highest value in stage 1, with $740.65 \mathrm{mM}$ Trolox $100 \mathrm{~g}^{-1}$ $\mathrm{fw}$, and decreased as the fruit matured until losing half of its value in the last stage of maturation. The opposite occurred in the cultivar 'GAL-T', which showed its lowest value in stage 1 and the highest in stage 4, with $719.83 \mathrm{mM}$ Trolox $100 \mathrm{~g}^{-1} \mathrm{fw}$.

For the antioxidant activity studied in L-TAA, something similar to H-TAA occurs, which shows its maximum activity in all the cultivars in stage 2, and decreases considerably as the fruit ripens. The highest value was again obtained in the cultivar 'MSI', with $1100.17 \mathrm{mM}$ Trolox $100 \mathrm{~g}^{-1} \mathrm{fw}$, followed by the variance 'GAL-E' with 854.54 and 'GAL-T' with $765.79 \mathrm{mM}$ Trolox $100 \mathrm{~g}^{-1} \mathrm{fw}$. Cultivars 'PSI' and 'DAT' showed the lowest value of 672.25 mM Trolox $100 \mathrm{~g}^{-1} \mathrm{fw}$ and $642.12 \mathrm{mM}$ Trolox $100 \mathrm{~g}^{-1} \mathrm{fw}$, respectively.

The highest content of TAA was shown by the DPPH method, with a value of $322.15 \mathrm{mM}$ Trolox $\mathrm{kg}^{-1} \mathrm{fw}$ in stage 4 in the cultivar 'GAL-T', followed by the cultivar 'DAT' in stage 4 and 'GAL-E' in stage 3 with a value of $298.04 \mathrm{mM}$ Trolox $\mathrm{kg}^{-1} \mathrm{fw}$ and $296.81 \mathrm{mM}$ Trolox $\mathrm{kg}^{-1} \mathrm{fw}$, respectively.

The antioxidant activity by FRAP showed the highest peaks in stage 4 of all cultivars, and the largest of these was in the cultivar 'PSI', with a value of $109.87 \mathrm{mM}$ Trolox $\mathrm{kg}^{-1} \mathrm{fw}$. With the ABTS method, the highest value was in the cultivar 'MSI', with $62.76 \mathrm{mM}$ Trolox $\mathrm{kg}^{-1}$ fw in stage 3 . 
Table 3. Total antioxidant activity (TAA) (mM Trolox fw) by the ABTS, DPPH, and FRAP methods and hydrophilic and lipophilic fractions in jujube fruits.

\begin{tabular}{|c|c|c|c|c|c|c|c|c|c|c|c|c|c|c|c|c|}
\hline \multirow[t]{2}{*}{ TAA } & \multirow[b]{2}{*}{ Stage 1} & \multicolumn{3}{|c|}{ 'GAL-E' } & \multicolumn{3}{|c|}{ 'GAL-T' } & \multicolumn{3}{|c|}{ 'MSI' } & \multicolumn{3}{|c|}{ 'PSI' } & \multicolumn{3}{|c|}{ 'DAT' } \\
\hline & & 740.65 & \pm 30.21 & $\mathrm{cC}$ & 455.61 & \pm 4.90 & $\mathrm{aA}$ & 819.63 & \pm 9.43 & $\mathrm{bD}$ & 826.64 & \pm 2.22 & $\mathrm{bD}$ & 643.46 & \pm 2.78 & $\mathrm{cB}$ \\
\hline H-TAA & Stage 2 & 650.93 & \pm 11.15 & $\mathrm{bA}$ & 704.09 & \pm 32.81 & $\mathrm{bA}$ & 941.24 & \pm 9.11 & $\mathrm{dD}$ & 864.02 & \pm 4.54 & $\mathrm{cC}$ & 794.63 & \pm 28.68 & $\mathrm{~dB}$ \\
\hline \multirow[t]{2}{*}{ mg Trolox $100 \mathrm{~g}^{-1} \mathrm{fw}$} & Stage 3 & 692.06 & \pm 30.99 & $\mathrm{bcC}$ & 495.79 & \pm 9.35 & $\mathrm{aB}$ & 775.23 & \pm 9.99 & $\mathrm{aD}$ & 833.41 & \pm 3.74 & $\mathrm{bE}$ & 375.70 & \pm 3.62 & $\mathrm{aA}$ \\
\hline & Stage 1 & 372.12 & \pm 33.95 & $\mathrm{aA}$ & 369.13 & \pm 19.61 & $\mathrm{aA}$ & 933.71 & \pm 4.65 & $\mathrm{bC}$ & 538.50 & \pm 11.31 & $\mathrm{bB}$ & 511.42 & \pm 5.19 & $\mathrm{cB}$ \\
\hline L-TAA & Stage 2 & 854.54 & \pm 5.70 & $\mathrm{cC}$ & 765.79 & \pm 19.52 & $\mathrm{bB}$ & 1100.17 & \pm 28.92 & $\mathrm{cD}$ & 672.25 & \pm 25.00 & $\mathrm{cA}$ & 642.12 & \pm 23.29 & $\mathrm{dA}$ \\
\hline \multirow[t]{2}{*}{$\mathrm{mg}$ Trolox $100 \mathrm{~g}^{-1} \mathrm{fw}$} & Stage 3 & 613.64 & \pm 27.26 & $\mathrm{bE}$ & 316.62 & \pm 15.90 & $\mathrm{aB}$ & 205.38 & \pm 26.54 & $\mathrm{aA}$ & 553.92 & \pm 9.69 & $\mathrm{bD}$ & 411.83 & \pm 16.60 & $\mathrm{bC}$ \\
\hline & Stage 4 & 146.50 & \pm 7.75 & $\mathrm{aE}$ & 158.57 & \pm 4.11 & $\mathrm{aB}$ & 212.43 & \pm 5.08 & $\mathrm{aA}$ & 171.78 & \pm 4.42 & $\mathrm{aD}$ & 97.11 & \pm 4.65 & $\mathrm{aC}$ \\
\hline ABTS & Stage 2 & 39.49 & \pm 4.77 & $\mathrm{aA}$ & 30.41 & \pm 1.66 & $\mathrm{aA}$ & 33.99 & \pm 3.54 & $\mathrm{aA}$ & 52.14 & \pm 4.09 & $\mathrm{aB}$ & 38.32 & \pm 1.04 & $\mathrm{bA}$ \\
\hline \multirow[t]{3}{*}{$\mathrm{mM}$ Trolox $\mathrm{kg}^{-1} \mathrm{fw}$} & Stage 3 & 34.79 & \pm 13.52 & $\mathrm{aA}$ & 39.42 & \pm 3.64 & $\mathrm{abA}$ & 62.76 & \pm 7.35 & $\mathrm{bA}$ & 38.05 & \pm 12.89 & $\mathrm{aA}$ & 43.54 & \pm 3.78 & $\mathrm{bA}$ \\
\hline & Stage 4 & 31.30 & \pm 0.53 & $\mathrm{aA}$ & 47.97 & \pm 1.16 & $\mathrm{bB}$ & 32.71 & \pm 1.44 & $\mathrm{aA}$ & 51.07 & \pm 6.54 & $\mathrm{aB}$ & 42.93 & \pm 5.34 & $\mathrm{bAB}$ \\
\hline & Stage 1 & 210.25 & \pm 5.90 & $\mathrm{aD}$ & 181.72 & \pm 11.16 & $\mathrm{aBC}$ & 197.78 & \pm 7.23 & $\mathrm{aCD}$ & 148.91 & \pm 3.33 & $\mathrm{aA}$ & 168.81 & \pm 10.44 & $\mathrm{aAB}$ \\
\hline $\mathrm{DPPH}$ & Stage 2 & 229.90 & \pm 8.56 & $\mathrm{aBC}$ & 223.97 & \pm 4.52 & $\mathrm{aBC}$ & 204.25 & \pm 12.28 & $\mathrm{aB}$ & 175.77 & \pm 11.83 & $\mathrm{abA}$ & 238.54 & \pm 4.26 & $\mathrm{bC}$ \\
\hline \multirow[t]{3}{*}{$\mathrm{mM}$ Trolox $\mathrm{kg}^{-1} \mathrm{fw}$} & Stage 3 & 296.81 & \pm 1.19 & $\mathrm{bD}$ & 224.81 & \pm 10.22 & $\mathrm{abB}$ & 259.07 & \pm 11.17 & $\mathrm{bC}$ & 182.73 & \pm 10.81 & $\mathrm{bA}$ & 293.01 & \pm 13.49 & $\mathrm{cD}$ \\
\hline & Stage 4 & 205.69 & \pm 3.06 & $\mathrm{aA}$ & 322.15 & \pm 8.43 & $\mathrm{bD}$ & 226.78 & \pm 1.38 & $\mathrm{aB}$ & 199.81 & \pm 4.91 & $\mathrm{bA}$ & 298.04 & \pm 4.37 & $\mathrm{cC}$ \\
\hline & Stage 1 & 37.03 & \pm 4.03 & abA & 39.24 & \pm 7.39 & $\mathrm{aA}$ & 75.65 & \pm 11.08 & $\mathrm{abB}$ & 44.62 & \pm 2.94 & $\mathrm{aA}$ & 33.33 & \pm 12.89 & $\mathrm{aA}$ \\
\hline \multirow{2}{*}{$\begin{array}{c}\text { FRAP } \\
\mathrm{mM} \text { Trolox } \mathrm{kg}^{-1} \mathrm{fw}\end{array}$} & Stage 2 & 23.56 & \pm 7.42 & $\mathrm{aA}$ & 66.48 & \pm 7.36 & $\mathrm{bC}$ & 58.74 & \pm 8.90 & $\mathrm{aBC}$ & 30.52 & \pm 10.76 & $\mathrm{aAB}$ & 44.34 & \pm 7.38 & $\mathrm{aABC}$ \\
\hline & Stage 4 & 52.21 & \pm 1.19 & $\mathrm{bA}$ & 74.60 & \pm 3.67 & $\mathrm{cB}$ & 82.89 & \pm 3.22 & $\mathrm{bB}$ & 109.87 & \pm 26.58 & $\mathrm{bB}$ & 56.39 & \pm 6.51 & $\mathrm{aA}$ \\
\hline
\end{tabular}

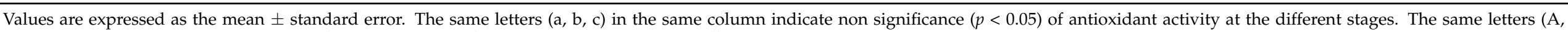

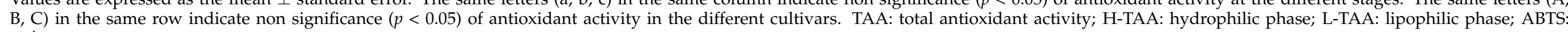

2,2'-azino-bis(3-ethylbenzothiazoline-6-sulphonic acid; DPPH: 2,2-diphenyl-1-picrylhydrazyl; FRAP: ferric reducing antioxidant power. 


\section{Discussion}

There was a significant difference in size among cultivars. In the cultivars 'GAL$\mathrm{E}^{\prime}$, 'GAL-T', and 'MSI', the maximum weight was reached in stage 3, while the cultivar 'PSI' had the highest weight in stage 2. These values were similar to the Chinese cultivar 'Zhanhua' [11]. The cultivars of greater weight and size were 'GAL-E' and 'GAL-T', which were much higher than those obtained by [11] in the study of Chinese cultivars in stage 1 and stage 2. These results are in agreement with those obtained in the cultivars 'Phoenix', 'Isidro', and 'Rate' in Spain [34].

Color is one of the most important quality parameters and determines consumers' acceptance. Along the maturation, the color changed from greener tones (stage 1), to white (stage 2), to yellows and reds (stage 3), and to higher red tones (stage 4). In Chinese cultivars, in their immature and mature stages, the $\mathrm{L}^{*}$ and $\mathrm{a}^{*}$ values were lower than in the Spanish cultivars. The Chinese cultivars 'Huanghua' and 'Zhanhua' obtained values in their most immature stage, stage 1 , for $L^{*}$ of 67.70 and 66.01 , respectively, and for $a^{*}$ of 11.31 and -112.08 [11], respectively, which were close to those obtained for the Spanish cultivars in their more mature stages. The values for $\mathrm{L}^{*}$ and $\mathrm{a}^{*}$, in their more mature stages, showed more proximity to the Spanish cultivar 'MSI' in stage 4 to the Chinese cultivar in the same stage. On the other hand, the $b^{*}$ parameter showed similar values to the Chinese cultivars in both stages. This assumes that Spanish cultivars were brighter and greener in their immature stages than Chinese cultivars. On the other hand, in their mature stages, they coincide more in the reddish tones. The Spanish cultivars 'MSI', 'PSI', and 'DAT' had very similar values in $L^{*}, a^{*}$, and $b^{*}$ to the Turkish fruits analyzed by [35], so they showed a similar color to Turkish fruits in all stages of maturity.

The content of proteins in jujube ranged from 0.36 to $0.76 \mathrm{mg} \mathrm{g}^{-1} \mathrm{fw}$. The proteins showed a high content in stage 1 and 2 . This protein value can even be halved in its last stage of maturation owing to the enzymatic synthesis that occurs in the fruit. These values agree with the mature stage of 'Rate' and 'Phoenix' [34]. Moreover, these contents were within the normal range for Spanish cultivars 'Jinjoles Grandes' and 'Jinjoles Medianos' [36], but lower than those reported in Chinese [37] and Korean cultivars [38].

The most important color pigments in jujube are carotenoids and chlorophylls [39]. The cultivar 'PSI' showed the highest carotenoid content in stage 2, followed by the cultivar 'MSI' in the most mature stage of the fruit and 'DAT' in stage 1. The GAL cultivars were the least carotenoid in their four stages.

The total content of chlorophylls was higher in the cultivars 'GAL-T', 'GAL-E', and 'PSI' in their more immature stages, stages 1 and 2. The 'GAL-T' cultivar was the one that showed a high level of total chlorophylls $\left(0.72 \mathrm{mg} 100 \mathrm{~g}^{-1} \mathrm{fw}\right)$, while 'DAT' obtained $0.26 \mathrm{mg} 100 \mathrm{~g}^{-1} \mathrm{fw}$. This behavior indicates the importance of chlorophylls in the maturity of the fruit, as they are responsible for the green color in its initial stages of maturation, and the chlorophylls decreased as the fruit matured [39].

Flavonoids are phenolic compounds that were also found at interesting levels in the jujube fruit, and it has been shown that these compounds have important pharmacological and biochemical properties [40]. The cultivars 'GAL-E', 'MSI', 'PSI', and 'DAT' showed very high values of phenols in stages 1 and 2 . The lowest values were obtained in the 'DAT' cultivars with $390.92 \mathrm{mg}$ GAE $100 \mathrm{~g}^{-1} \mathrm{fw}$ and 'GAL-T' with $340.92 \mathrm{mg}$ GAE $100 \mathrm{~g}^{-1} \mathrm{fw}$ for the same stage. These values were similar to those obtained for the Turkish cultivar in similar maturation stage [34]. 'MSI' and 'PSI' obtained a content of phenols in their mature stage very similar to those of the cultivars 'Lingbaozao' and 'Zanhuangzao' in the mature stage [41].

In cultivars 'GAL-E', 'GAL-T', and 'MSI', stage 2 was where the highest content of flavonoids was reached, which decreased considerably as the fruit matured. The cultivar 'DAT' in stage 1 already obtained its highest value, of $100.14 \mu \mathrm{g}$ eq. rutin $100 \mathrm{~g}^{-1} \mathrm{fw}$, which gradually decreased until stage 4 , with the lowest value of $47.92 \mu \mathrm{g}$ eq. rutin $100 \mathrm{~g}^{-1} \mathrm{fw}$. The values obtained were close to the Chinese cultivars 'Zanhuangzao' and 'Lizao' in a similar maturation stage [41]. This content of flavonoids was similar to that of some fruits 
such as strawberry (147.8 mg GAE $\left.100 \mathrm{~g}^{-1} \mathrm{fw}\right)$, lemon (66.3 mg GAE $\left.100 \mathrm{~g}^{-1} \mathrm{fw}\right)$, peach (65.3 mg GAE $100 \mathrm{~g}^{-1} \mathrm{fw}$ ), and banana (56.1 mg GAE $100 \mathrm{~g}^{-1} \mathrm{fw}$ ) [42].

Regarding flavonols, they reached their highest value in stage 2 of cultivars 'GAL$E^{\prime}$ ' and 'GAL-T', while cultivar 'DAT' had the highest value in stage 1. Cultivars 'MSI' and 'PSI' showed the highest content in flavonols in stage 4 . In all cultivars except the latter two, the flavonols obtained the highest value in their most immature stages and decreased, as did the flavonoids, as the stage of maturity of the jujube fruit increased. This behavior was similar to that shown by [43], where the content of phenols, flavonoids, and flavonols showed a decrease as maturation increased. What leads to the content of phenolic compounds, in addition to being related to the stages of maturity, is also associated with the red color shown by the fruit in its more mature stages [44].

The study showed that jujube is rich in phenolic compounds and, consumed fresh, can be a good source of phenols in the diet. The highest content of these compounds may be due to the genotype, time of harvest, climatic conditions, and agronomic practices. Even the part of the fruit is another aspect to take into account, as there can be up to five times more compounds in the peel than in the pulp [34].

The total antioxidant activity was quantified in jujubes by three methods (ABTS, DPPH, and FRAP) in four different stages of maturity. The antioxidant activity in the hydrophilic and lipophilic fractions by the ABTS method was also studied.

In general, the antioxidant activity in H-TAA and L-TAA was higher in the more immature stages of the fruit, whereas the antioxidant activity by ABTS, DPPH, and FRAP was higher in their more mature stages, that is, stage 3 and, above all, stage 4 . This fact is interesting, as jujube does not lose its antioxidant capacity as it matures, which means it has health benefits regardless of the stage of maturity in which it is consumed. These results are in concordance with [45].

The antioxidant activity in H-TAA took place in stage 2, where it reached the highest value, which then decreased in stage 3 and, in some cases, it rose again in stage 4 in a small proportion. On the other hand, the cultivar 'GAL-E' showed its highest value in stage 1, which decreased as the fruit matured until losing half of its value at the last stage of maturation. The opposite occurred in the cultivar 'GAL-T', which may be due to the fact that, despite being the same cultivar, the agronomic conditions of the tree were very different, and the antioxidant activity in H-TAA varies considerably from one stage to another, although the total content is very similar.

The highest content of TAA was shown by the DPPH method, and the antioxidant activity by FRAP showed the highest peaks in stage 4 of all cultivars. With the ABTS method, the highest value was in the cultivar 'MSI' in stage 3 . These values were similar to those obtained in stage 3 and 4 by [34].

\section{Conclusions}

The stage of development significantly influenced the physicochemical and antioxidant activity with regard to five jujube cultivars.

Fruits changed from green in their most immature stages to red in the most mature stage. Chlorophylls and carotenoids explain this change during ripening in cultivars, which decrease as maturation increases. The largest fruits in terms of weight and dimensions were those of the 'GAL-E' and 'GAL-T' variety, by far. Then follow those of the cultivar 'MSI', which were medium sized, and finally those of the cultivars 'PSI' and 'DAT'. The fruits of the latter were striking for their elongated shape.

The content of phenols was high in all the cultivars, and 'GAL-T' and 'MSI' showed a high content in their more mature stages. The flavonoids showed a high content in the most immature stages, except the cultivar 'PSI'. The antioxidant activity by the methods ABTS, DPPH, and FRAP showed the highest activity during the last stages of maturation, stage 3 and 4. By the ABTS method, the cultivar 'MSI' was found to have the highest peak; by the DPPH method, this was the cultivar 'DAT'; and by the FRAP method, this was the cultivar 'PSI'. In contrast, the antioxidant activity of the hydrophilic and lipophilic fractions 
by the ABTS method showed the highest level in stage 2 and 3 in the cultivar MSI. That was why the jujube could be used as a natural antioxidant extract. It was shown to be a rich source of phenolic compounds and antioxidants in the four stages of maturity studied, but the most interesting stages for its collection are stages 2 and 3.

Author Contributions: J.R. and A.A. performed the experiments and wrote the manuscript; J.R. and M.S.A. analyzed the data and methodology; F.H. and P.L. planned and designed the experiments and coordinated the study. All authors have read and agreed to the published version of the manuscript.

Funding: This research was funded by Consellería de Educación, Investigación, Cultura y Deportes of the Generalitat Valenciana (AICO-2016/015).

Acknowledgments: The authors are thankful to Monserrate García, for providing jujube samples.

Conflicts of Interest: The authors declare no conflict of interest.

\section{References}

1. Wang, B.; Huang, Q.; Venkitasamy, C.; Chai, H.; Gao, H.; Cheng, N.; Cao, W.; Lv, X.; Pan, Z. Changes in phenolic compounds and their antioxidant capacities in jujube (Ziziphus jujuba Miller) during three edible maturity stages. LWT 2016, 66, 56-62. [CrossRef]

2. Collado-González, J.; Cruz, Z.N.; Medina, S.; Mellisho, C.D.; Rodríguez, P.; Galindo, A.; Egea, I.; Romojaro, F.; Ferreres, F.; Torrecillas, A.; et al. Effects of water deficit during maturation on amino acids and jujube fruit eating quality. Maced. J. Chem. Chem. Eng. 2014, 33, 105-119. [CrossRef]

3. Sun, Y.F.; Liang, Z.S.; Shan, C.J.; Viernstein, H.; Unger, F. Comprehensive evaluation of natural antioxidants and antioxidant potentials in Ziziphus jujuba Mill. var. spinosa (Bunge) Hu ex H. F. Chou fruits based on geographical origin by TOPSIS method. Food Chem. 2011, 124, 1612-1619. [CrossRef]

4. Agustí, M. Crecimiento y Maduración del Fruto. En Fundamentos de Fisiología Vegetal, 2nd ed.; Azcón-Bieto, J., Talón, M., Eds.; McGraw-Hill/Interamericana de España: Barcelona, Spain, 2008; pp. 519-535.

5. Rhodes, M.J.C. The climacteric and ripening of frutis. In The Biochemistry of Fruit and Their Products, 2nd ed.; Hulme, A.C., Ed.; Academic Press: London, UK, 1970; pp. 521-533.

6. Giovannoni, J. Molecular biology of fruit maturation and ripening. Annu. Rev. Plant Physiol. 2001, 52, 725-749. [CrossRef]

7. Krska, B.; Mishra, S. Sensory evaluation of different products of Ziziphus jujuba Mill. Acta Hort. 2009, 840, 557-562. [CrossRef]

8. Patel, P.R.; Rao, T.V.R. Physiological changes in relation to growth and ripening of Khirni Manilkara hexandra (Roxb.) Dubard fruit. Fruits 2009, 64, 139-146. [CrossRef]

9. Brummell, D.A. Cell wall disassembly in ripening fruit. Funct. Plant Biol. 2006, 33, 103-119. [CrossRef]

10. Prasanna, V.; Prabha, T.N.; Tharanathan, R.N. Fruit ripening phenomena-an overview. Crit. Rev. Food Sci. Nutr. 2007, 47, 1-19. [CrossRef]

11. Wang, H.; Chen, F.; Yang, H.; Chen, Y.; Zhang, L.; An, H. Effects of ripening stage and cultivar on physicochemical properties and pectin nanostructures of jujubes. Carbohydr. Polym. 2012, 89, 1180-1188. [CrossRef]

12. Ambasta, S.P. The Useful Plants of India. Publications and Information Directorate; CSIR: New Delhi, India, $1986 ;$ p. 918.

13. Erenmemisoglu, A.; Keletimur, F.; Koker, A.H.; Utsuol, H.; Tekol, Y.; Ustdal, M. Hypoglycemic activity of Zizyphus jujuba. J. Pharm. Pharmacol. 1995, 47, 72-74. [CrossRef]

14. Peng, W.; Hsieh, M.; Lee, Y.; Lin, Y.; Liao, J. Anxiolytic effect of seed of Ziziphus jujuba in mouse models of anxiety. J. Ethnopharmacol. 2000, 72, 435-441. [CrossRef]

15. Elmahi, M.; Essassi, E.M.; Hamamouchi, M.; Hamamouchi, J. Study on the antimicrobial and antibilharzia activity of Ziziphus vulgaris. Fitoterapia 1997, 68, 34-36.

16. Ghasemzadeh, A.; Ghasemzadeh, N. Flavonoids and phenolic acids: Role and biochemical activity in plants and human. J. Med. Plant Res. 2011, 5, 6697-6703. [CrossRef]

17. Dai, J.; Mumper, R.J. Plant phenolics: Extraction, analysis and their antioxidant and anticancer properties. Molecules 2010, 15, 7313-7352. [CrossRef] [PubMed]

18. Prior, R.L. Absorption and Metabolism of anthocyanins: Potential Health Effects. In Phytochemicals: Mechanisms of Action, 1st ed.; Mepeel, M.S., Bidlack, W.R., Davies, A.J., Eds.; CRC Press: Boca Raton, FL, USA, 2004; pp. 1-19.

19. Jiang, J.G.; Huang, X.J.; Chen, J.; Lin, Q.S. Comparison of the sedative and hypnotic effects of flavonoids, saponins, and polysaccharides extracted from Semen Ziziphus jujube. Nat. Prod. Res. 2007, 21, 310-320. [CrossRef]

20. Guo, S.; Duan, J.A.; Tang, Y.; Qian, D.; Zhu, Z.; Qian, Y.; Shang, E.; Su, S. UHPLC-TOFMS coupled with chemometric method as a powerful technique for rapid exploring of differentiating components between two Ziziphus species. J. Sep. Sci. 2011, 34, 659-666. [CrossRef]

21. Kevers, C.; Falkowski, M.; Tabart, J.; Defraigne, J.; Dommes, J.; Pincemail, J. Evolution of antioxidant capacity during storage of selected fruit and vegetables. J. Agric. Food Chem. 2007, 55, 8596-8603. [CrossRef]

22. Celik, H.; Ozgen, M.; Serce, S.; Kaya, C. Phytochemical accumulation and antioxidant capacity at four maturity stages of cranberry fruit. Sci. Hort. 2008, 117, 345-348. [CrossRef] 
23. Villa-Rodríguez, J.A.; Molina-Corral, F.J.; Ayala-Zavala, J.F.; Olivas, G.I.; González-Aguilar, G.A. Effect of maturity stage on the content of fatty acids and antioxidant activity of 'Hass' avocado. Food Res. Int. 2011, 44, 1231-1237. [CrossRef]

24. Valero, D.; Díaz-Mula, H.M.; Zapata, P.J.; Castillo, S.; Guillén, F.; Martínez-Romero, D.; Serrano, M. Postharvest treatments with salicylic acid, acetylsalicylic acid or oxalic acid delayed ripening and enhanced bioactive compounds and antioxidant capacity in sweet cherry. J. Agric. Food Chem. 2011, 59, 5483-5489. [CrossRef]

25. Bradford, M. A rapid and sensitive method for the quantitation of microgram quantities of protein utilizing the principle of protein-dye binding. Anal. Biochem. 1976, 72, 248-254. [CrossRef]

26. Arnao, M.B.; Cano, A.; Acosta, M. The hydrophilic and lipophilic contribution to total antioxidant activity. Food Chem. 2001, 73, 239-244. [CrossRef]

27. Re, R.; Pellegrini, N.; Proteggente, A.; Pannala, A.; Yang, M.; Rice-Evans, C. Antioxidant activity applying an improved ABTS radical cation decolorization assay. Free Radic. Biol. Med. 1999, 26, 1231-1237. [CrossRef]

28. Brand-Williams, W.; Cuvelier, M.E.; Berset, C. Use of a free radical method to evaluate antioxidant activity. J. Food Sci. Technol. 1995, 28, 25-30. [CrossRef]

29. Benzie, I.; Strain, J.J. The ferric reducing ability of plasma (FRAP) as a measure of "antioxidant power": The FRAP assay. Anal. Biochem. 1996, 239, 70-76. [CrossRef] [PubMed]

30. Wojdyło, A.; Oszmiański, J.; Bielicki, P. Polyphenolic composition, antioxidant activity, and polyphenol oxidase (PPO) activity of quince (Cydonia oblonga Miller) varieties. J. Agric. Food Chem. 2013, 61, 2762-2772. [CrossRef]

31. Singleton, V.L.; Orthofer, R.; Lamuela-Raventos, R.M. Analysis of total phenols and other oxidation substrates and antioxidants by means of Folin-Ciocalteu reagent. Methods Enzymol. 1999, 299, 152-178.

32. Zhuang, L. Extraction and determination of flavonoid in ginkgo. Chin. Herb. Med. 1992, 23, 122-124.

33. Kumaran, S.P.; Kutty, B.C.; Chatterji, A.; Subrayan, P.P.; Mishra, K.P. Radioprotection against DNA damage by an extract of Indian green mussel Perna viridis (L). J. Environ. Pathol. Toxicol. Oncol. 2007, 26, 263-272. [CrossRef]

34. Reche, J.; Hernández, F.; Almansa, M.S.; Carbonell-Barrachina, A.A.; Legua, P.; Amorós, A. Physicochemical and nutritional composition, volatile profile and antioxidant activity differences in Spanish jujube fruits. LWT 2018, 98, 1-8. [CrossRef]

35. Gündüz, K.; Saraçoğlu, O. Changes in chemical composition, total phenolic content and antioxidant activities of jujube (Ziziphus jujuba Mill.) fruits at different maturation stages. Acta Sci. Pol. Hortorum Cultus 2014, 13, 187-195.

36. Almansa, S.; Hernández, F.; Legua, P.; Nicolás-Almansa, M.; Amorós, A. Physico-chemical and physiological changes during fruit development and on-tree ripening of two Spanish jujube cultivars (Ziziphus jujuba Mill.). J. Sci. Food Agri. 2016, 96, 4098-4105. [CrossRef] [PubMed]

37. Li, J.W.; Fan, L.P.; Ding, S.D.; Ding, X.L. Nutritional composition of five cultivars of Chinese jujube. Food Chem. 2007, 103, 454-460. [CrossRef]

38. Choi, S.H.; Ahn, J.B.; Kim, J.J.; Im, N.K.; Kozukue, N.; Levin, C.E. Changes in free amino acids, protein, and flavonoid content in jujube (Ziziphus jujuba) fruit during eight stages of growth and antioxidative and cancer cell inhibitory effects by extracts. J. Agric. Food Chem. 2012, 60, 10245-10255. [CrossRef] [PubMed]

39. Lancaster, J.E.; Lister, C.E.; Reavy, P.; Triggs, C. Influence of pigment composition on peel color in a wide range of fruit and vegetables. J. Am. Soc. Hortic. Sci. 1997, 122, 594-598. [CrossRef]

40. Al-Niami, J.H.; Saggar, R.A.M.; Abbas, M.F. The physiology of ripening of jujube fruit (Ziziphus spina-christi L. Willd.). Sci. Hort. 1992, 51, 303-308. [CrossRef]

41. Kang, W.Y.; Li, C.F.; Liu, Y.X. Antioxidant phenolic compounds and flavonoids of Mitragyna rotundifolia (Roxb.) Kuntze in vitro. Med. Chem. Res. 2010, 19, 1222-1232. [CrossRef]

42. Gao, Q.H.; Wu, P.T.; Liu, J.R.; Wu, C.S.; Parry, J.W.M. Physicochemical properties and antioxidant capacity of different jujube (Ziziphus jujube Mill.) cultivars grown in loess plateau of China. Sci. Hort. 2011, 130, 67-72. [CrossRef]

43. Carlsen, M.H.; Halvorsen, B.L.; Holte, K.; Bohn, S.K.; Dragland, S.; Sampson, L.; Willey, C.; Senoo, H.; Umezono, Y.; Sanada, C.; et al. The total antioxidant content of more than 3100 foods, beverages, spices, herbs and supplements used worldwide. J. Nutr. 2010, 9, 3. [CrossRef]

44. Zozio, S.; Serveng, A.; Cazal, G.; Mbeguie, A.; Ravion, S.; Pallet, D.; Abel, H. Changes in antioxidant activity during the ripening of jujube (Ziziphus mauritiana Lamk). Food Chem. 2014, 150, 448-456. [CrossRef]

45. Xie, P.P.; You, F.; Huang, L.; Zhang, C. Comprehensive assessment of phenolic compounds and antioxidant performance in the developmental process of jujube (Ziziphus jujube Mill.). J. Funct. Foods 2017, 36, 233-242. [CrossRef] 